\title{
Propaganda i rzeczywistość nazistowska widziana oczami dziecka w powieści Johna Boyne'a Chtopiec w pasiastej piżamie
}

Bruno się zamyślił.

Przywołując w pamięci obraz ludzi w pasiastych piżamach, zastanawiał się, o co właściwie chodzi z tym Po-Świeciem [... $]^{1}$

Bruno ma dziewięć lat. Nic nie wie o ideologii III Rzeszy i ostatecznym rozwiązaniu kwestii żydowskiej (niem. Endlösung der Judenfrage). Jego sielankowe życie w realiach Berlina, pośród przyjaciół i rodziny, w tym ukochanej babci i dziadka, przerwane zostaje już na pierwszej karcie powieści awansem jego ojca i przeprowadzką do tajemniczego miejsca zwanego Po-Świeciem (niem. Aus-Wisch). Chłopiec nie ma ,pojęcia, na czym polega praca jego ojca”2. Snucie wyobrażeń, że ten być może jest sprzedawcą warzyw, nauczycielem lub też szefem kuchni, siłą rzeczy oddala go od prawdy o awansie ojca na komendanta obozu koncentracyjnego. Przeprowadzka do Po-Świecia w roku 1943 stanowi cezurę w dotychczasowym życiu i percepcji świata u chłopca, jego dwunastoletniej siostry Gretel i ich matki.

Bruno poczuł ból żołądka i coś w nim zaczęło puchnąć, coś, co po wydostaniu się z najskrytszych jego głębin na światło dzienne może doprowadzić albo do dzikich wrzasków, że cała ta przeprowadzka jest potężnym nieporozumieniem, pomyłką, za którą ktoś zapłaci, albo też po prostu do wybuchu płaczu. Nie umiał się z tym wszystkim pogodzić. Żadną miarą. Dopiero co bawił się wesoło w domu, miał trzech najwierniejszych przyjaciół, zjeżdżał po poręczy i stawał na palcach, żeby oglądać Berlin, a teraz nagle ten dom, zimny i paskudny, z trzema szepczącymi pokojówkami

* Dr, e-mail: pawel.moskala@uj.edu.pl; Uniwersytet Jagielloński, Wydział Filologiczny, Instytut Filologii Germańskiej, Zakład Literatury Niemieckiej.

${ }^{1}$ J. Boyne, Chłopiec w pasiastej piżamie, przekł. P. Łopatka, Wydawnictwo Replika, Zakrzewo 2013, s. 158.

2 Tamże, s. 10. 
i smutnym oraz zagniewanym służącym, gdzie nic nie wskazuje, by kiedyś jeszcze mogli zaznać szczęścia ${ }^{3}$.

Bruno musi zaakceptować przeprowadzkę, której zasadność ojciec tłumaczy obowiązkami zawodowymi: „To moja praca, bardzo ważna dla mnie. Ważna dla naszego kraju. Jak również dla Furii. Kiedyś to zrozumiesz" ". Argumenty ojca nie niwelują uczucia smutku, nostalgii i samotności. Wydawać by się mogło, że jedyne, co trzyma chłopca przy życiu, to jego wrodzony instynkt odkrywcy, będący pewnego dnia przyczyną osobliwej wycieczki „wzdłuż tajemniczego ogrodzenia, które zdawało się ciągnąć parę kilometrów". Po blisko godzinnym marszu chłopiec spotyka po drugiej stronie ogrodzenia syna żydowskiego zegarmistrza o imieniu Schmul. Mniejszy od Bruna, chudy i brudny, w pasiastej piżamie i płóciennej czapce, bez butów i skarpet, za to z gwiazdą na ramieniu, sprawia na nim wrażenie strasznie smutnego ${ }^{6}$. Liczne rozmowy i wspólne zabawy, które dzieci organizują sobie mimo dzielącego ich ogrodzenia, szybko pieczętują przyjaźń obu i budzą u Brunona z jednej strony narastające wątpliwości, z drugiej natomiast coraz większą empatię w stosunku do Schmula. Gotowość niesienia pomocy przynosi Brunonowi niespodziewaną zgubę. Zakłada on „pasiaste spodnie, pasiastą górę od piżamy i płócienną czapkę identyczną" jak Szmul, przechodzi pod ogrodzeniami, pomaga przyjacielowi odnaleźć zaginionego ojca. Obaj chłopcy, zamknięci „, nieprzeniknionym mroku i zgiełku”, ze ściśniętymi dłońmi, dzielą ostatecznie tragiczny los wielu milionów zagazowanych w komorach?

Akcja powieści Johna Boyne’a rozgrywa się na dwóch płaszczyznach narracyjnych. Czas akcji osadzony jest w tajemniczym Po-Świeciu, gdzie oprócz zakamuflowanego obozu koncentracyjnego znajduje się również nowy dom Brunona. Dom

całkiem samotnie na jakimś pustkowiu i w zasięgu wzroku nie było żadnych innych, co oznaczało, że wokół nikt nie mieszkał, [...] wokół nowego domu ulic nie było wcale, nikt tu się nie przechadzał ani nie gnał w pośpiechu i nie było choćby jednego sklepu czy straganu owocowo-warzywnego ${ }^{8}$.

Nowa rzeczywistość szybko uświadamia chłopcu, że „tutaj nie ma powodu do śmiechu ani w ogóle do radości”’9. Akcja z jednej strony zogniskowana jest

\footnotetext{
${ }^{3}$ Tamże, s. 20.

${ }^{4}$ Tamże, s. 49.

${ }^{5}$ Tamże, s. 100.

${ }^{6}$ Tamże, s. 102.

${ }^{7}$ Tamże, s. 197.

${ }^{8}$ Tamże, s. $16-17$.

${ }^{9}$ Tamże, s. 18.
} 
wokół nowego domu oraz przylegającego do niego obozu koncentracyjnego, dla którego ważnym punktem odniesienia staje się symboliczne ogrodzenie, z drugiej natomiast - przepleciona wspomnieniami Brunona pochodzącymi jeszcze $\mathrm{z}$ Berlina. Tak skonstruowana fabuła sugeruje swój dalszy bieg w nurcie powieści rozwojowej, ukazującej proces dojrzewania chłopca w wymiarze intelektualnym, charakterologicznym, afektywnym i społecznym. Jego rozwój jednak, podobnie jak w przypadku milionów podobnych mu wiekiem dzieci, których los zdeterminowała przynależność rasowa, przerwany zostaje szybką śmiercią.

Krótki, bo zaledwie roczny pobyt chłopca w Po-Świeciu, stygmatyzują ograniczenia jego możliwości poznawczych i nazistowska propaganda, której działania - co należy zresztą do istoty tejże - chłopiec sobie nie uświadamia. Dzieje się tak pomimo wrodzonego instynktu odkrywcy, który podpowiada mu, że obraz prawdy poddany jest niezrozumiałemu dla niego zabiegowi deformacji. Zniekształcenie rzeczywistości odbywa się poprzez zabiegi propagandowe, których twórcą - w ujęciu Bogusławy Dobek-Ostrowskiej - jest każdorazowo organizacja bądź instytucja, zaś jej działania komunikacyjne są profesjonalnie zaplanowane i zarządzane ${ }^{10}$. Wśród głównych celów propagandy nazistowskiej Krzysztof Grzegorzewski wymienia ,utrwalenie w społeczności niemieckiej (i, jak się później okaże, także europejskiej) stereotypowego obrazu Żyda"'11. Józef Kossecki natomiast sytuuje punkt ciężkości po stronie pragmatyzmu i upatruje w zabiegach propagandowych przede wszystkim sposobu werbowania kolejnych ludzi na potrzeby organizacji nazistowskiej ${ }^{12}$. Tak ukierunkowaną propagandę, posługującą się agitacją, można odnaleźć także w powieści Chłopiec $w$ pasiastej piżamie, niemniej jednak nie stanowi ona w książce motywu dominującego. Ustępuje bowiem zabiegom propagandowym zogniskowanym na kontroli przepływu informacji dla zatajenia prawdy o realiach otaczających Brunona w PoŚwieciu. Cenzurowanie prawdy jest procesem zintegrowanym i wielopłaszczyznowym, w którym dwie dominanty odgrywają rolę decydującą. Po pierwsze, skrzętnie zatajona przed chłopcem pozostaje wiedza na temat funkcji, jaką sprawuje jego ojciec, jak również na temat rzeczywistej roli obozu. Przedstawiany jest on bowiem jako farma, na której rolnicy uprawiają ziemię, ale jej obraz zostaje zniekształcony odkryciem samego Brunona, że ,w tym piachu nic się nie da wyhodować"13 i że ,po drugiej stronie ogrodzenia [...] są setki dzieci"14.

\footnotetext{
${ }^{10}$ Por. B. Dobek-Ostrowska, Komunikowanie polityczne i publiczne, Wydawnictwo Naukowe PWN, Warszawa 2011, s. 203.

${ }^{11}$ K. Grzegorzewski, ,Judenfrage”. Retoryczny obraz propagandy antysemickiej w III Rzeszy (na przykładzie publicznych wypowiedzi Adolfa Hitlera i innych polityków NSDAP w latach 1933-1945), „Acta Universitatis Lodziensis. Folia Litteraria Polonica” 2011, nr 14, s. 142.

12 Por. J. Kossecki, Totalna wojna informacyjna XX wieku a II RP, Wydawnictwo WSP, Kielce 1997, s. 14.

${ }^{13}$ J. Boyne, dz. cyt., s. 37.

${ }^{14}$ Tamże, s. 178.
} 
Po drugie, zauważyć należy kontrolę przepływu informacji w samym wymiarze topograficznym otoczenia, które stało się nowym domem młodego człowieka. Reglamentowanie prawdy odbywa się bowiem poprzez ograniczenie jego przestrzeni życiowej, której azymuty wyznaczają mu dom oraz przylegający do niego ogród otoczony ogrodzeniem i zwieńczony tajemniczą furtką, do której nie wolno się chłopcu zbliżać. Typowy dla propagandy nazistowskiej zabieg kreowania alternatywnej rzeczywistości ma za zadanie dostarczyć możliwie idyllicznego obrazu otaczającego go świata i pohamować jednocześnie jego niebezpieczną - w oczach twórców systemu - ciekawość świata. System nazistowski ogranicza zatem możliwości poznawcze chłopca, starając się jednocześnie, przy użyciu chociażby technik operacyjnych ${ }^{15}$, pozyskać jak najwięcej informacji o swych obywatelach. Tym samym odwołuje się do „pędu poznawczego”, tak skrzętnie poskramianego chociażby w wymiarze przestrzennym u Brunona, który, posługując się słowami Briana Anse Patricka z 10 przykazań propagandy, sam przecież ,penetruje poznawczo"16.

Kompleksowość zabiegów propagandowych obejmuje z jednej strony dawkowanie informacji, z drugiej natomiast wychowanie młodego pokolenia, któremu system przypisuje a priori określoną rolę do spełnienia. Jak konkluduje Leonard Doob: ,propaganda ma oddziaływać na osobowość celem sprawowania kontroli nad ludzkim zachowaniem"17. Jej istotnym wyznacznikiem jest publiczna manifestacja symboli nazizmu i tym samym identyfikacja z poglądami i wartościami propagowanymi przez ustrój. Do najważniejszych w powieści należą bez wątpienia: mundur żołnierski wraz z czerwono-czarnymi opaskami, pasiaste „piżamy” osób z „farmy” i służby w domu czy wreszcie pozdrowienie niemieckie (niem. Deutscher Gruß) stosowane na powitanie i pożegnanie, mające ukazać jedność narodu niemieckiego oraz posłuszeństwo wobec jego wodza i kanclerza. Jakkolwiek pierwsze trzy symbole budzą jedynie mniejsze lub większe zaciekawienie Brunona, tak ojcowskie lekcje salutowania mają skutkować wyraźną identyfikacją chłopca z ustrojem:

Przed wyjściem ustawili się w rzędzie, jak ołowiane żołnierzyki, i każdy zasalutował w taki sposób, jak ojciec uczył Brunona: ściągnąwszy palce dłoni, z ramieniem uniesionym ku górze w prędkim, szorstkim geście, wyrzucając dwa słowa, które Bruno miał powtarzać zawsze, gdy je tylko słyszy ${ }^{18}$.

\footnotetext{
${ }^{15}$ Por. P. Cieślar, Operacje i techniki operacyjne, Wydawnictwo AON, Warszawa 2009.

${ }^{16}$ Por. B.A. Patrick, 10 przykazań propagandy, przeł. J. Sugiero, Wydawnictwo Helion, Gliwice 2015, s. 115.

${ }^{17}$ L. Doob, Public Opinion and Propaganda, Cresset Press, London 1949, s. 240.

${ }^{18}$ J. Boyne, dz. cyt., s. 45.
} 
Nauka salutowania jest może najbardziej jaskrawym, ale nie jedynym elementem musztry, jakiej poddawany jest chłopiec. Jej widocznym celem jest nauczenie dziecka zachowania odpowiedniego do zaistniałej sytuacji, ukrytym natomiast - ukształtowanie postawy obywatelskiej oczekiwanej przez system nazistowski, w którym posłuszeństwo, nihilizm moralny, atmosfera czujności i strachu są głównymi elementami:

- Po pierwsze - ciągnął ojciec - kiedy przyjdzie Furia, macie bez słowa stanąc w holu, gotowi na powitanie. Nie wolno się odzywać, póki do was nie przemówi. Wtedy należy mu odpowiedzieć jak najstaranniej i wyraźnie. Zrozumiano? [...] - Trzeba otwierać usta i mówić jak dorośli. Pod żadnym pozorem nie możecie zachowywać się jak dzieci. Jeśli Furia was zlekceważy, to tak samo macie milczeć, powinniście jednak patrzeć przed siebie i okazywać mu szacunek oraz grzeczność należne wielkiemu przywódcy ${ }^{19}$.

Na innej karcie powieści komendant obozu przytacza jako wzór siebie i swojego ojca, którego bezkompromisowe i surowe metody wychowawcze doprowadziły go do pełnienia wysokich funkcji powierzonych przez Furię: „Sądzisz, że osiągnąłbym aż tyle, gdybym wreszcie nie pojął, kiedy się warto sprzeczać, a kiedy milczeć i być posłusznym?"20.

Indoktrynacja Brunona i jego siostry, opierająca się na symbolice oraz posługująca się kłamstwem, półprawdą i manipulacją, ma służyć kształtowaniu poglądów i charakteru dzieci w duchu ideologii nazistowskiej, w czym szczególną rolę odgrywa wynajęty przez ojca nauczyciel Herr Liszt. Propaganda agitacyjna Liszta, upowszechniająca i umacniająca określone wzorce, bazuje na zagadnieniach z dwóch dziedzin nauki - historii i geografii, które dostarczając wiedzy o „tożsamości, dziedzictwie, pochodzeniu"21, warunkują "gruntowne rozumienie nauk społecznych"22. Celem propagandy, zdaniem Macieja Szymanowskiego, nie jest stricte kreowanie rzeczywistości, lecz ukierunkowanie na nią reakcji człowieka. Najlepszym do tego mechanizmem jest nieustanny proces przekonywania $\mathrm{w}$ oparciu o poznanie indywidualne (bezpośredni kontakt z rzeczywistością) i symboliczne (odbicie rzeczywistości za pośrednictwem pisma, obrazu, dźwięku czy też przekazu ustnego) w celu pozyskania go do określonych racji, idei i wartości ${ }^{23}$.

Efekty propagandowej ideologii Herr Liszta, która - zgodnie z terminologią Gartha Jowetta i Victorii O’Donnell - posługuje się kanałem perswazyjno-

19 Tamże, s. 114.

${ }^{20}$ Tamże, s. 51.

${ }^{21}$ Tamże, s. 94.

22 Tamże, s. 93.

${ }^{23}$ Por. M. Szymanowski, Wartości narodowe w komunistycznej propagandzie Czechosłowacji, Polski i Weggier w prasie lat 1949-1953, Księgarnia Akademicka, Kraków 2010, s. 20. 
-informacyjnym i przy tym wymusza przekonania, zachowania oraz reakcje oczekiwane przez nadawcę, a adaptowane przez odbiorcę ${ }^{24}$, można zaobserwować w pokoju siostry Brunona. Gretel wszystkie swoje lalki zastępuje podarowanymi przez ojca mapami Europy, a następnie codziennie wbija w nie szpileczki i po lekturze gazet - ku uciesze Herr Liszta - niczym wytrawny taktyk symbolicznie je przesuwa, śledząc ruchy wojsk na frontach walk ${ }^{25}$. Tym samym dziewczynka dowodzi swojej bierności wobec zabiegów komunikacyjno-medialnych i staje się reprezentantką społeczeństwa masowego, na które dominujący wpływ wywiera indoktrynacja nazistowska ${ }^{26}$. Rolę propagandy w działaniach wojennych trafnie ujął już w latach dwudziestych amerykański socjolog mediów, Harold Dwight Lasswell: „W wielkim społeczeństwie nie da się już stopić indywidualnych poglądów jednostek w wielkim piecu wojennego tańca, potrzeba nowego, subtelniejszego instrumentu, który scali tysiące i miliony ludzi w jednolitą masę nienawiści, woli i nadziei" 27.

Mechanizm demagogii i manipulacji, rozpowszechniony przez nazistowską propagandę i stosowany również przez Herr Liszta, oddziałując na świadomość człowieka, ma - zdaniem Mariusza Mazura - pozyskiwać zwolenników dla głoszonych idei ${ }^{28}$, ale nie sprawdza się w przypadku Brunona. Tym samym jedna z kluczowych funkcji propagandy, ideowo-wychowawcza, nie tylko nie zostaje zrealizowana, lecz przeciwnie - wywołuje u chłopca efekt odwrotny do zamierzonego w postaci narastających wątpliwości: „Bruno się zamyślił. Przywołując w pamięci obraz ludzi w pasiastych piżamach, zastanawiał się, o co właściwie chodzi z tym Po-Świeciem, czy coś tu przypadkiem nie gra, skoro ci wszyscy ludzie nabierają tak chorego wyglądu" 29 . Prawdziwych informacji dostarcza mu siostra, która - zirytowana dziecinnymi pytaniami brata - porządkuje chłopcu obraz rzeczywistości w duchu nazizmu, starając się przy tym pozbawić go iluzorycznej percepcji otaczających ich realiów. Informuje, że Żydów należy izolować, „żeby się z nami nie kontaktowali”, a tajemnicze ogrodzenie „ma uniemożliwić przechodzenie" do nich gatunku, który chłopiec dla zrozumienia zawiłości świata nazywa Przeciwieństwem ${ }^{30}$, en passant sugerując dychotomiczny podział na swoich i obcych. Gretel upomina ponadto brata, że miejsce ich obecnego zamiesz-

${ }^{24}$ G.S. Jowett, V. O'Donnell, Propaganda as a form of Communication, za: B. Dobek-Ostrowska, dz. cyt., s. 205.

${ }^{25}$ J. Boyne, dz. cyt., s. 168 i 176.

${ }^{26}$ Por. S.J. Baran, D.K. Davis, Teorie komunikowania masowego, przeł. A. Sadza, Wydawnictwo Uniwersytetu Jagiellońskiego, Kraków 2007, s. 77.

${ }^{27}$ Por. H.D. Lasswell, Propaganda Technique in the World War, Alfred A. Knopf, New York 1927, s. 221.

28 Por. M. Mazur, Propagandowy obraz świata. Polityczne kampanie prasowe w PRL 1956-1980, Wydawnictwo Trio, Warszawa 2003, s. 19.

${ }^{29}$ J. Boyne, dz. cyt., s. 158.

${ }^{30}$ Tamże, s. 170 i 171. 
kania „to nie jest żadne Po-Świecie”, manifestując jednocześnie, iż „w historii ludzkości nikt się jeszcze bardziej nie omylił" "31. Na wcześniejszej karcie powieści sam ojciec informuje Brunona, że Żydzi „to nie ludzie [...]. No, w każdym razie nie w naszym rozumieniu tego słowa"32. Jego komunikat nie ma jedynie funkcji informatywnej, lecz odwołuje się także do tak ważnych dla retoryki nazistów emocji, wśród których dominuje strach. Chcąc uspokoić syna, komendant zapewnia, że ten nie powinien się niczym martwić, ponieważ oddziela go od Żydów ogrodzenie, które uniemożliwia im kontakt ${ }^{33}$.

Nieliczne podobne fragmenty egzemplifikujące retorykę propagandy, która - zdaniem Marka Ostrowskiego - kreuje „spiskową wizję świata, czyli przeświadczenie, że wróg czai się wszędzie" 34 , są tym bardziej wymowne w całej książce, że propaganda na płaszczyźnie werbalnej pozostaje silnie zredukowana, a ikoniczne motywy, takie jak: druty, pasiasta piżama, płócienna czapka, hełmy, jaskrawe czerwono-czarne opaski czy broń na ramieniu, występują rzadko, tworząc jednakże za każdym razem analogie do prawdy historycznej:

Naturalnie czasem te dwie grupy się łączyły. Bruno nieraz widywał ludzi ze swojej strony ogrodzenia po stronie przeciwnej i z jego obserwacji niezbicie wynikało, że ci sprawują władzę. Za każdym razem, gdy się u nich zjawiali żołnierze, „piżamowcy” stawali na baczność, padali na ziemię, a czasem wcale nie wstawali, tak że ich trzeba było wynosićc ${ }^{35}$.

Propaganda nazistowska rezygnuje nie tylko z typowej dla siebie nomenklatury, żeby zbudować poczucie przynależności i jedności, lecz także z przejawów depersonalizacji i dehumanizacji osób znajdujących się po drugiej stronie ogrodzenia. Brak jest w powieści scen psychicznego i cielesnego poniżania, pobicia, gwałtów, zabijania. Ukazany zostaje jedynie efekt końcowy w postaci podbitego oka Schmula, nagłego wyjazdu z Po-Świecia oficera, który zataił przed komendantem ucieczkę swojego ojca z kraju, czy też wynoszonych z ,farmy” przez żołnierzy dziwnie nieruchomych ,piżamowców”. Rezygnacja w tekście z charakterystycznego dla nomenklatury nazistowskiej skomplikowanego języka wypowiedzi, wypełnionego dygresjami, hipotaksą i kompleksowymi konstrukcjami gramatycznymi, jak strona bierna i tryb warunkowy ${ }^{36}$, czy wreszcie z ukazywania przejawów depersonalizacji i dehumanizacji, jest wynikiem prowadzenia

${ }^{31}$ Tamże, s. 169.

32 J. Boyne, dz. cyt., s. 54.

${ }^{33}$ Tamże.

${ }^{34}$ M. Ostrowski, Literatura obozowa w jej funkcji ,oral history” a propaganda PRL, Wydawnictwo Primum Verbum, Łódź 2013, s. 56.

35 J. Boyne, dz. cyt., s. 97.

${ }^{36}$ Por. K. Grzegorzewski, dz. cyt., s. 144. 
narracji z perspektywy dziecka, które dostrzega jedynie mały wycinek prawdy i raczej sensorycznie wyczuwa niepokój, niż umie zlokalizować jego źródło: „[Szmul] Był mniejszy od Brunona i siedział na ziemi z żałosną miną. Miał na sobie pasiastą piżamę i płócienną czapkę, jak wszyscy po tamtej stronie ogrodzenia. Był bez butów i skarpetek i miał strasznie brudne nogi, a na ramieniu opaskę z gwiazdą" 37 .

Narracja z perspektywy chłopca ma swoje odbicie także w samej warstwie językowej, gdzie można odnaleźć wszystkie rodzaje zdań współrzędnie i podrzędnie złożonych, nie występują natomiast zdania wielokrotnie złożone. Brak jest przy tym użycia typowego dla technik propagandowych stopnia najwyższego przymiotników, eufemizmów, metafor czy wreszcie języka technicznego i/lub pseudonaukowego. Propaganda w Po-Świeciu nie ma zatem swojego źródła w samej warstwie językowej, lecz zogniskowana jest na ograniczeniu przepływu informacji i budowaniu poczucia strachu, niepewności i bezradności. Próby zrzucenia współodpowiedzialności za rzeczywistość można szukać chociażby w stwierdzeniu, iż „wszelkie decyzje podejmują za nas pewne osoby"38. Niepewność wywołuje poczucie strachu, który paraliżuje Brunona do tego stopnia, iż ten zataja przed oficerem prawdę o wręczeniu Schmulowi plastrów „,faszerowanego kurczaka"39, przyczyniając się tym samym do jego ukarania: „Twarz [Szmul] miał tak posiniaczoną, że ze zdumienia Bruno na sekundę zapomniał o przeprosinach" ${ }^{40}$. Strach dotyka również ojca chłopca, zdeklarowanego zwolennika jedynie słusznej doktryny, z jednej strony symbolu władzy, z drugiej - posłuszeństwa i lojalności: „Ciekawe, co pomyślą, jak ci pozwolę samej z dziećmi [słowa te kieruje komendant (ojciec) do matki Brunona] wracać do Berlina? - spytał ojciec. - Zaraz nabiorą wątpliwości co do mojego zaangażowania w pracęe"41.

Pojęciu ,praca" przypisana jest w powieści rola równie istotna jak w ideologii nazistowskiej, przy czym jej wymiar etyczny manifestują dwie skrajności. Z jednej strony, silne poczucie obowiązku i znaczenia wykonywanej pracy, które miał komendant, manifestujące się m.in. próbami zintensyfikowania eksterminacji, $z$ drugiej natomiast, etyczny apel żony i jej starania o przywrócenie słowom pierwotnego znaczenia: „Pracę?! - wykrzyknęła matka. - Ty to nazywasz pracą?”42. Opór żony i babci, który ze względu na przypisaną ich płci rolę społeczną okazać się może jedynie symboliczny, przeciwstawiony zostaje zdecydowanym przekonaniom komendanta i jego ojca o słuszności reprezentowanych postaw oraz poglądów, co ugruntowane jest m.in. siłą bezosobowej machiny wojennej, której

\footnotetext{
${ }^{37}$ J. Boyne, dz. cyt., s. 102.

38 Tamże, s. 18.

39 Tamże, s. 159.

${ }^{40}$ Tamże, s. 163.

${ }^{41}$ Tamże, s. 175.

42 J. Boyne, dz. cyt., s. 175.
} 
twarzą są identycznie wyglądający oficerowie stanowiący nieodzowne decorum domu, ogrodu i ,farmy”.

W przypadku Brunona propaganda ponosi klęskę ze względu na ukierunkowanie na jednostkę, a nie, jak to miało miejsce w narodowym socjalizmie, na odbiorcę masowego. Pozostaje ona niedostosowana do potrzeb odbiorcy, który poznaje świat nie poprzez studiowanie książek ideologicznych, ale empirycznie - przeżywając świat zewnętrzny. Jej mankamentem jest zatem - parafrazując słowa Michała Szulczewskiego - atrakcyjna perswazja ukierunkowana na dotarcie do adresata, która apeluje zarówno do motywacji altruistycznych, czyli wykazuje zbieżności propagowanych idei z interesem ogółu, jak i niealtruistycznych, odwołujących się do bodźców ${ }^{43}$. Symbolicznym odpowiednikiem Brunona jest jego żydowski przyjaciel Schmul, do którego chłopak ostatecznie się upodabnia: goli włosy, zakłada kraciastą piżamę i przechodzi na drugą stronę ogrodzenia w poszukiwaniu jego zaginionego ojca. Razem stają się ikoną uwikłania dziecka w mechanizm historii, przy czym nie następuje identyfikacja czytelnika ani z oprawcą, ani z ofiarą, ponieważ ich światy stają się wraz z biegiem akcji coraz mniej rozgraniczone. Dochodzi do odwrócenia schematu ofiara-oprawca, dla zrozumienia którego cennych badań dostarczył w latach siedemdziesiątych psycholog społeczny Stanley Milgram. ${ }^{44}$ Charakter apelatywny powieści ukazuje zarówno mechanizmy propagandy i jej wpływu na rozwój jednostki (dziecka), jak również możliwości odwrócenia ról społecznych w zmieniających się warunkach i wreszcie odwołuje się do postaw etycznych. Wyraźna staje się przy tym, chociażby z uwagi na dziecięcą perspektywę narratora, rezygnacja z wartościowania, moralizowania, formułowania sądów, heroizowania ofiar i demonizowania oprawców.

Kompozycja powieści na płaszczyźnie konstrukcji bohaterów pozostaje przy tym w sprzeczności z modelem struktury władzy systemu nazistowskiego. Brak jest bowiem koncentracji na jednej osobie, jak w przypadku przywództwa Hitlera. Wiecznie zajęty komendant obozu nie tylko jest postacią drugoplanową, ale i jego władztwo systematycznie jest podważane licznymi kłótniami z żoną i matką. Losy Brunona, będącego wprawdzie głównym bohaterem powieści, splatają się natomiast nierozłącznie z losami jego żydowskiego przyjaciela, a ich dopełnieniem jest gęsta sieć innych postaci, których epizodyczne przygody tworzą obraz modelu struktury władzy nazizmu, ujawniając jego idee, postawy i metody postępowania. Uderzająca jest przy tym typowa dla nurtu literatury obozowej rezygnacja z patetycznego języka i literackości kosztem faktograficznego przedstawienia zdarzeń, przy czym nie brakuje fragmentów o silnym zabarwieniu emocjonalnym.

${ }^{43}$ M. Szulczewski, Propaganda polityczna. Zarys problematyki teoretycznej, Wydawnictwo Książka i Wiedza, Warszawa 1972, s. 69 i 70.

${ }^{44}$ S. Milgram, Obedience to Authority: An Experimental View, New York 1974; T. Butler-Bowdon, 50 Klassiker der Psychologie, München 2013. 


\section{Bibliografia}

Baran S.J., Davis D.K., Teorie komunikowania masowego, przeł. A. Sadza, Wydawnictwo Uniwersytetu Jagiellońskiego, Kraków 2007.

Boyne J., Chłopiec w pasiastej piżamie, przeł. P. Łopatka, Wydawnictwo Replika, Zakrzewo 2013.

Cieślar P., Operacje i techniki operacyjne, Wydawnictwo AON, Warszawa 2009.

Dobek-Ostrowska B., Komunikowanie polityczne i publiczne, Wydawnictwo Naukowe PWN, Warszawa 2011.

Doob L., Public Opinion and Propaganda, Cresset Press, London 1949.

Grzegorzewski K., ,,Judenfrage”. Retoryczny obraz propagandy antysemickiej w III Rzeszy (na przykładzie publicznych wypowiedzi Adolfa Hitlera i innych polityków NSDAP $w$ latach 1933-1945), „Acta Universitatis Lodziensis. Folia Litteraria Polonica” 2011, nr 14, s. 141-153.

Karwat M., Sztuka manipulacji politycznej, Wydawnictwo Adam Marszałek, Toruń 2001.

Kossecki J., Totalna wojna informacyjna XX wieku a II RP, Wydawnictwo WSP, Kielce 1997.

Lasswell H.D., Propaganda Technique in the World War, Alfred A. Knopf, New York 1927.

Mazur M., Propagandowy obraz świata. Polityczne kampanie prasowe w PRL 1956-1980, Wydawnictwo Trio, Warszawa 2003.

Ostrowski M., Literatura obozowa w jej funkcji ,oral history” a propaganda PRL, Wydawnictwo Primum Verbum, Łódź 2013.

Patrick B.A., 10 przykazań propagandy, przekł. J. Sugiero, Wydawnictwo Helion, Gliwice 2015.

Szulczewski M., Propaganda polityczna. Zarys problematyki teoretycznej, Wydawnictwo Książka i Wiedza, Warszawa 1972.

Szymanowski M., Wartości narodowe w komunistycznej propagandzie Czechosłowacji, Polski $i$ Węgier w prasie lat 1949-1953, Księgarnia Akademicka, Kraków 2010.

Welch D., The Third Reich. Politics and Propaganda, Routledge, London, New York 1995.

Paweł Moskała

\section{The propaganda and the Nazi reality as seen through the eyes of a child in John Boyne's The Boy in the Striped Pyjamas}

\section{(Summary)}

The aim of the article is to present the Nazi reality and its propaganda as seen through the eyes of Bruno - the hero of the novel John Boyne's The Boy in the Striped Pyjamas. The narrative shown from the perspective of a child reveals, in a unique way, the mechanics of demagogy and manipulation used by the Nazi propaganda. The symbolic fence between Bruno, the son of the concentration camp commandant, and a Jewish boy of the same age named Schmul, becomes the main theme of the novel. The story of the novel reveals the entanglement of the children in the workings of the history. Such a story construction is a starting point for the author of the article for the analysis of the complexity of propaganda measures and their influence on a young person, mainly in the affective, intellectual and social dimensions. The analysis involves not only the linguistic layer of the novel, but also the topography of the place and the characteristic use of Nazi symbols.

Keywords: Nazi propaganda, concentration camp, fence, racial identity, Jew, perpetrator, victim. 